\title{
EKSTRAK ETHANOL PEGAGAN (Centella asiatica) MENINGKATKAN OSIFIKASI TULANG DAN PANJANG BADAN LARVA ZEBRAFISH (Danio rerio) MODEL STUNTING USIA 9 HARI PASCA FERTILISASI (Ethanolic extract of Centella asiatica increase bone ossification and increase the body length and in zebrafish (Danio rario) larvae Stunting Model at 9 day post fertilization)
}

\author{
Evi Zahara $^{1^{*}}$, Een Nuraenah ${ }^{2}$, Tri Yuliyani $^{3}$, Darwitri $^{4}$, Husnul Khotimah $^{5}$, Umi Kalsum $^{5}$, I Wayan Arsana Wiyasa $^{5}$, \\ Nurlaili Ramli, Agus Hendra Al-Rahmad ${ }^{7}$, Mohammad Muljohadi Ali ${ }^{5}$ \\ ${ }^{1}$ Program Studi D-III Kebidanan Meulaboh, politeknik Kesehatan Kemenkes, Aceh, Indonesia. Email: \\ zaharaevi@yahoo.com \\ ${ }^{2}$ Program Studi D-III Kebidanan politeknik Kesehatan Kemenkes, Jakarta III,. Indonesia, enadha.nuraenah@gmail.com. \\ ${ }^{3}$ Dinas Kesehatan Banjar, Kalimantan Selatan, Indonesia, Email: yuliyani1907@gmail.com \\ ${ }^{4}$ Program Studi D-III Kebidana politeknik Kesehatan Kemenkes, Tanjungpinang, Indonesia, dwitri84@gmail.com \\ ${ }^{5}$ Department Farmakologi, Fakultas Kedokteran. Universitas Brawijaya, Malang, Indonesia. Email: \\ husnul_farmako.fk@ub.ac.id \\ ${ }^{5}$ Departement of Obstetric and Gynecology, Saiful Anwar Hospital, Fakultas Kedokteran. Universitas Brawijaya, \\ Malang, Indonesia. Email ; arsanawaiyasa@gmail.com. \\ ${ }^{6}$ Program Studi D-IV Kebidanan politeknik Kesehatan Kemenkes, Aceh, Indonesia. Email: \\ nurlaili.ramli@poltekkesaceh.ac.id \\ ${ }^{7}$ Jurusan Gizi Politeknik Kesehatan Kemenkes, Aceh, Indonesia. Email: 4605.ah@gmail.com
}

\begin{abstract}
ABSTRAK
Centella asiatica (Linn) Urban dikenal dengan nama pegagan. Centella Asiatica (CA) kaya akan mikro maupun makro nutrisi yang diperlukan bagi tubuh terutama masa pertumbuhan. Penelitian ini bertujuan mengetahui efek ekstrak etanol CA terhadap osifikasi tulang dan panjang badan larva zebrafish model stunting yang diinduksi rotenone pada 9 hari post fertilisasi. Penelitian ini menggunakan zebrafish mulai 2 hpf (hour post fertilisation) - 9 dpf (day post fertilisation), populasi larva sejumlah 300 yang dibagi 5 kelompok yang terdiri dari kelompok kontrol, kelompok rotenon (dipapar rotenone 12,5 ppb) dan 3 kelompok rotenone + CA yang diberikan pegagan selama 4, 5 dan 6 hari secara berurutan. Ekstrak CA diperoleh melalui metode maserasi dengan pelarut etanol. Hasil penelitian menunjukkan bahwa rotenone dapat menghambat pertumbuhan panjang larva $>2 S D$ dan menurunkan osifikasi tulang pada kelompok rotenon secara signifikan dibanding kontrol. Pemberian ekstrak CA dapat meningkatkan ekspresi tulang rawan kelompok rotenone + CA5 maupun rotenone + CA6 dan meningkatkan ekspresi tulang keras kelompok rotenone $+C A 5$ serta meningkatkan panjang badan kelompok rotenone_CA secara signifikan dibanding kelompok rotenone. Dapat disimpulkan bahwa lamanya pemberian ekstrak CA dapat meningkatkan osifikasi tulang dan meningkatkan panjang badan mencapai $99.6 \%$ pada $9 \mathrm{dpf}$
\end{abstract}

Kata kunci: Zebrafish, Centella asiatica, osifikasi tulang, panjang badan.

*Penulis untuk korespondensi: zaharaevi@yahoo.com

\begin{abstract}
Centella asiatica (Linn) Urban is known as Gotu Kola. Centella asiatica (CA) is rich of micro and macro nutrients. The aim of this study was to investigate the effect of ethanol extract of CA on bone ossification and body length in zebrafish larva stunting model at 9 dpf. This study used zebrafish at 2 hpf (hour post-fertilization) - 9 dpf (day post fertilization). The population of 300 larvae divided into 5 groups consisting of control group, rotenone group (exposed by 12.5 ppb of rotenone) and 3 rotenone $+C A$ groups that exposed to CA extract for 4, 5 and 6 days, respectively. The CA extract was obtained by maceration method with ethanol solvent. The results showed that rotenone 12,5 ppb able to inhibit the growth of larvae >2SD of body length and decrease bone ossificatio at rotenone group, were significantly different from the control group. Administration of CA extract was increase expression of cartilage at rotenone $+C A 5$ as well rotenone + CA6 group and increase expression of bone at rotenone $+C A 5$ group and also increase body length rotenone $+C A$ groups significantty different from rotenone group. It can be concluded that the period of CA extract exposured can correct the length of the body reaching $99.6 \%$ at 9 dpf and increased bone ossification in time dependent manner.
\end{abstract}

Keywords: Zebrafish, Centella asiatica, bone ossification, body length. 


\section{PENDAHULUAN}

Stunting merupakan suatu keadaan dimana panjang atau tinggi badan melebihi -2 SD dari rata-rata anak pada usia dan jenis kelamin yang sama. $^{1}$ Stunting diidentifikasikan sebagai prioritas utama kesehatan global karena kejadian stunting yang tinggi. ${ }^{2}$ Tingginya prevalensi anak stunting (37.2\%) membuat Indonesia masuk dalam lima besar di dunia. ${ }^{3}$ Kematian anak secara global mencapai $14-17 \%$ akibat stunting. ${ }^{4}$ Dampak stunting jangka panjang meliputi keterbatasan kognitif dan performa pendidikan ${ }^{5}$ produktifitas ekonomi dewasa yang lebih rendah dan resiko mewarisi stunting pada generasi selanjutnya. ${ }^{6}$ Proses stunting sudah dimulai sejak masa pranatal dan diketahui pada usia 2 tahun. $^{7}$ Stunting bisa disebabkan karena toksikan, inflamasi, malnutrisi, infeksi berkelanjutan dan faktor lingkungan. ${ }^{8}$

Pertumbuhan panjang badan erat kaitannya dengan osifikasi tulang yang sedang berlangsung. Osifikasi merupakan merupakan proses pembentukan tulang. Dimana sel masenkim dan kartilago diubah menjadi tulang selama perkembangan. Pertumbuhan tulang rawan dibutuhkan untuk penambahan panjang tulang panjang, selanjutnya tulang rawan ini akan digantikan oleh sel- sel tulang pembentuk tulang (osteoblast). ${ }^{9}$ Osteoblast selanjutnya menjadi osteosit (sel tulang matang pembentuk tulang) yang tertanam kuat pada matriks tulang. ${ }^{10}$

Penggunaan pestisida sebagai salah satu faktor lingkungan dapat memicu terjadinya stunting. Rotenone merupakan salah satu pestisida dengan konsentrasi 12,5 ppb mampu menginduksi stunting. ${ }^{11}$ Rotenon bekerja menghambat kompleks I mitokondria dan menghambat proses sintesis ATP sehingga jumlah ATP menurun dan memicu peningkatan Reactive Oxygen Species (ROS) yang dapat menyebabkan kematian sel dan bahaya oksidatif lainnya. ${ }^{12}$ Stres oksidatif dapat meningkatkan osteoklastogenesis oleh RANKL yang selanjutnya menghambat diferensiasi osteoblast yang berdampak pada hambatan pertumbuhan tulang. ${ }^{13}$

Centella asiatica (CA) merupakan tumbuhan yang kaya akan nutrisi. Zat gizi makro yang terkandung dalam CA berupa karbohidrat sebesar $6.7 \%$, protein $2 \%$ dan lemak $0.2 \% .^{14}$ Adapun kandungan zat gizi mikro dari $100 \mathrm{~g} \mathrm{CA}$ adalah $\mathrm{Na} 107.8 \mathrm{mg}$, K $345 \mathrm{mg}$, Ca $174 \mathrm{mg} \mathrm{Mg}$ $87 \mathrm{mg}, \mathrm{P} 17 \mathrm{mg}$ dan $\mathrm{Fe} 14.86 \mathrm{mg} \cdot{ }^{14}$ Centella asiatica juga kaya akan fitonutrient berupa vitamin A sebanyak $0.44 \mathrm{mg}, \mathrm{B} 10.09 \mathrm{mg}, \mathrm{B} 2$ $0.19 \mathrm{mg}$, B3 $0.1 \mathrm{mg}$ dan vitamin C $48.5 \mathrm{mg}{ }^{15}$ Selain nutrisi CA juga memiliki kandungan bahan aktif penting berupa saponin dan triterpenoid yang meliputi: asiaticosida, madekasosida, asiatic asid dan cetelloside yang dapat berperan sebagai anti oksidan. ${ }^{16}$ Penelitian sebelumnya menunjukkan bahwa dengan pemberian ekstrak CA konsentrasi $5 \mu \mathrm{g} / \mathrm{mL}$ prehatching paling optimal meningkatkan panjang badan larva zebrafish dibanding konsentrasi $1,25 \mu \mathrm{g} / \mathrm{mL}$ maupun $2,5 \mu \mathrm{g} / \mathrm{mL}$ melalui peningkatan ekspresi IGF-1 dan IRS, ${ }^{19}$ peningkatan osifikasi tulang dan penurunan ekspresi RANKL. ${ }^{11}$

Berdasarkan uraian diatas maka penelitian ini dilakukan untuk mengetahui efek ekstrak etanol Centella asiatica pre sampai post hatching terhadap osifikasi tulang dan panjang badan larva zebrafish stunting usia 9 dpf yang diinduksi rotenon.

\section{METODE}

Penelitian ini adalah true experimental laboratoric menggunakan desain post test only control group.

\section{Subjek Penelitian}

Penelitian ini menggunakan embrio zebrafish (Danio rerio) usia $2 \mathrm{hpf}$ yang selanjutnya diikuti perkembangannya sampai usia 9 dpf yang diperoleh dari hasil fertilisasi zebrafish dewasa wild type. Zebrafish dewasa diperoleh dari laboratorium Farmakologi Fakultas Kedokteran Universitas Brawijaya (FKUB) Malang yang telah diuji dan tersertifikasi di laboratorium Hidrologi Fakultas Perikanan Universitas Brawijaya. ${ }^{18}$

\section{Persiapan ekstrak etanol Centella asiatica}

Simplicia Centella asiatica tersertifikasi oleh UPT Materia Medica Batu, Malang, Jawa Timur, Indonesia. Salah satu zat aktif yang 
terkandung dalam $\mathrm{CA}$ adalah Asiaticoside 0,29\%. Pengukuran Asiticoside menggunakan LC-MS (Liquid Chromatography-Mass Spectrometry) (Thermo Scientific, Accela). Bagian CA yang digunakan dalam penelitian ini adalah daun tanpa stolon dan akar. ${ }^{18}$ Ekstraksi dilakukan dengan cara maserasi 100 gram simplicia CA diperoleh ekstrak CA sebanyak 10.99 gram. Ekatrak CA dilarutkan dengan embrionik medium. Larutan ekstrak etanol CA yang digunakan dalam penelitian ini adalah $5 \mu \mathrm{g}$ / $\mathrm{mL}$.

\section{Pembuatan larutan rotenone}

Rotenon yang digunakan berasal dari sigma (R8875) kemurniannya $\geq 95 \%$. Serbuk rotenon dilarutkan dalam DMSO sebagai stok dengan konsentrasi $2 \times 10^{7} \mu \mathrm{g} / \mathrm{L}$, selanjutnya diencerkan sampai mencapai 12,5 ppb dengan embrionic medium. ${ }^{18}$

\section{Embrionic Medium}

Larutan stok embrionik medium disiapkan dalam $200 \mathrm{ml}$ terkandung $0,08 \mathrm{~g} \mathrm{CaCl}, \mathrm{KCl}$ $0,06 \mathrm{~g}, \mathrm{NaCl} 2 \mathrm{~g}, \mathrm{MgSO} 4$ 0,815 g (modifikasi penelitian terdahulu). ${ }^{19}$

\section{Perlakuan Penelitian}

Dalam penelitian ini, larva zebrafish dari 2 hpf dibagi menjadi 5 kelompok dengan masingmasing kelompok berisi 60 embrio yang ditempatkan di well plate, sehingga total sampel adalah 300 embrio.

Larva zebrafish di bagi dalam 5 kelompok yaitu:

a. Kontrol (K) larva yang tidak diberikan paparan rotenon dan Centella asiatica.

b. Rotenon (R) yang hanya diberikan paparan rotenone konsentrasi $12,5 \mathrm{ppb}$ usia $2-72 \mathrm{hpf}$.

c. Rotenon+CA4 adalah sampel yang diberikan paparan rotenone $12,5 \mathrm{ppb}$ usia $2-72 \mathrm{hpf}$ dan ditambah pemberian larutan ekstrak etanol Centella asiatica dosis $5 \mu \mathrm{g} / \mathrm{ml}$ usia $2 \mathrm{hpf}-4 \mathrm{dpf}$.

d. Rotenon+CA5 adalah sampel yang diberikan paparan rotenone pada usia $2 \mathrm{hpf}-72 \mathrm{hpf}$ dan ditambah pemberian larutan ekstrak Centella dosis $5 \mu \mathrm{g} / \mathrm{ml}$ pada usia $2 \mathrm{hpf}-5 \mathrm{dpf}$.

e. Rotenon+CA6 adalah sampel yang diberikan paparan rotenone pada usia $2 \mathrm{hpf}-72 \mathrm{hpf}$ dan ditambah pemberian larutan ekstrak etanol Centella dosis $5 \mu \mathrm{g} / \mathrm{ml}$ usia $2 \mathrm{hpf}-6 \mathrm{dpf}$.

\section{Pengukuran Panjang Badan}

Pengukuran panjang badan dilakukan setiap 24 jam pada usia 3 sampai 9 dpf, dengan cara menempatkan larva zebrafish pada objek glass dengan air minimal, posisi larva diatur sedemikian rupa dan diamati dengan mikroskop stereo (Olympus SZ61) selanjutnya difoto mengunakan software optilab versi 2.2.1 dan mengukur Standar Leght (SL) menggunakan skala pada software immage Raster ver.3 yang sudah dikalibrasi sebelumnya. Pengukuran panjang badan larva mulai dari ujung hidung (tip of the snout) sampai pangkal sirip ekor (caudal fin) atau snout-fin. ${ }^{20}$ Pengukuran rasio panjang kepala dan panjang badan larva zebrafish yaitu, dari snout-operkulum dan dibandingkan dengan hasil pengukuran keseluruhan panjang larva (ujung hidung ke pangkal sirip ekor) pengukuran menggunakan satuan mm (milimeter). ${ }^{19}$

\section{Pengukuran Osifikasi Tulang}

Pengukuran tulang larva zebrafish dilakukan pada usia $9 \mathrm{dpf}$ dengan metode wholemount immunohistochemistry. Larva yang telah di-euthanasia ditempatkan dalam PFA 4\% selama 2 jam. ${ }^{21}$ Jumlah sampel untuk pewarnaan ini adalah 5 zebrafish untuk masing-masing kelompok.

\section{a. Tulang Rawan}

Pewarnaan tulang rawan menggunakan larutan Alcian blue (ANC030 dari ScyTek Laboratories). Prosedur pewarnaan Alcian Blue mengikuti protokol kerja ScyTek Laboratories. Larva diinkubasi dalam larutan Asam Asetat selama 3 menit dan dalam larutan Alcian Blue (pH 2,5) selama 30 menit pada suhu kamar atau 15 menit pada $37^{\circ} \mathrm{C}$. Larva dibilas selama 2 menit dengan aquadest sebanyak 2 kali. Dehidrasi dengan alkohol tergradasi kemudian ditempankan ke $87 \%$ gliserol dan dilakukan pengambilan gambar.

\section{b. Tulang Keras}

Pewarnaan tulang keras menggunakan Alizarin red (Art 6279 Alizarinrot S) $1 \mathrm{mg} / \mathrm{ml}$. Protokol pewarnaan Alizarin red adalah larva 
zebrafish tetap dalam alkohol $96 \%$ selama 12 jam, direndam larva dalam aquadest selama 1 malam, kemudian dalam $1 \% \mathrm{KOH}$ dengan $3 \%$ hidrogen peroksida $(5 \mathrm{ml} \mathrm{3 \%} \mathrm{H} 2 \mathrm{O} 2+100 \mathrm{ml} 1 \%$ $\mathrm{KOH})$ untuk 15 menit. Larva dicuci selama 10 menit dalam air suling, kemudian direndam dalam larutan Alizarin red $1 \mathrm{mg} / \mathrm{ml}(0,005 \%)$ selama 3 hari, dan dibilas $5 x$ dengan aquadest dan kemudian ditempankan ke $87 \%$ gliserol selanjutnya dapat diamati kepadatan warna tulang.

Hasil pewarnaan Alcian Blue dan Alizarin Red diamati di bawah mikroskop stereo (Olympus SZ61). Pengambilan gambar menggunakan DSLR Panasonic DMC-G6 Lumix pembesaran 40x. Pengukuran kepadatan warna (Integrated Density) menggunakan perangkat lunak Image J v1.50.

\section{Ethical clearance}

Prosedur dalam penelitian ini telah memenuhi standar protokol Komite Etika Kedokteran Universitas Brawijaya Malang Indonesia nomor 403 / EC / KEPK / 12/2017.

\section{Analisis statistik}

Analisis statistik menggunakan software SPSS V.23. Untuk mengetahui perbedaan antar kelompok digunakan uji One Way ANOVA. Data disajikan dalam mean \pm standar deviasi dan dianggap signifikan jika $\mathrm{p}<0,05$.

\section{HASIL DAN PEMBAHASAN}

\section{Efek Ekstrak Centella asiatica terhadap Osifikasi Tulang}

Hasil menunjukkan bahwa kelompok rotenon mengalami penurunan ekspresi tulang rawan dan tulang keras secara signifikan dibandingkan dengan kelompok kontrol yang di ukur pada usia 9 dpf seperti ditunjukkan pada tabel 1 dan gambar 1 .

Hasil penelitian ini juga didukung oleh penelitian sebelumya dimana rotenon $12,5 \mathrm{ppb}$ telah terbukti menyebabkan stunting dengan menurunkan IGF-1, ${ }^{17}$ penurunan osifikasi tulang. ${ }^{11}$ Rotenon dapat menghambat kompleks I mitokondria dan menghambat NADHubiquinone reduktase. Proses ini menyebabkan peningkatan ROS berlebih ${ }^{22}$ mengganggu sintesa ATP tulang rawan, ${ }^{23}$ menyebabkan peningkatan apoptosis. ${ }^{24,25}$ ROS yang berlebihan di dalam tubuh menyebabkan ketidakseimbangan antar pro-oksidan dan antioksidan dengan skala yang mengarah ke kelebihan pro-oksidan sebagai ciri terjadinya stres oksidatif. ${ }^{26}$ Beberapa penelitian lainnya melaporkan dampak stres oksidatif pada diferensiasi osteoklas serta pada fungsinya yang menghasilkan peningkatan resorpsi tulang. ${ }^{27}$ Penelitian in vitro dan hewan telah menunjukkan bahwa stres oksidatif mengurangi tingkat pembentukan tulang dengan mengurangi diferensiasi dan kelangsungan hidup osteoblas. ${ }^{28}$ Apoptosis bone lining cells yang tinggi berpengaruh terhadap proses pembentukan tulang baru. ${ }^{24}$ Peningkatan status oksidatif menyebabkan up-regulasi RANKL dan dan down-regulasi osteoprotegrin (OPG) melalui aktivasi protein kinase (ERK1/2, JNK dll) dan atau faktor lain yang mempengaruhi faktor transkripsi spesifik. ${ }^{29}$ RANKL mengaktifkan diferensiasi dan aktifitas osteoclast yang berinteraksi dengan reseptor spesifik di preosteoclast dan memediasi osteclastogenesis serta resorpsi tulang. Sedangkan OPG diproduksi oleh jalur pensinyalan WNT/ $\beta$ catenin merupakan soluble reseptor yang mampu mengikat dan memblokir RANKL yang dapat menghambat aktivitas osteoclast. ${ }^{30}$

Pemberian ekstrak etanol CA $5 \mu \mathrm{g} / \mathrm{mL}$ pada kelompok rotenon+CA5 dan rotenon+CA6 meningkatkan ekspresi tulang rawan dan tulang keras secara signifikan pada larva zebrafish usia 9 dpf dibanding kelompok rotenon seperti yang ditunjukkan pada tabel 2. Dari pewarnaan tulang rawan dan tulang keras larva zebrafish $9 \mathrm{dpf}$ menunjukkan ekspresi tulang rawan dan tulang keras lebih kuat pada kelompok rotenon+CA5 dan rotenon+CA6 dibanding kelompok rotenon seperti pada gambar 2 .

Centella asiatica dengan kandungan bahan aktif Asiaticoside berperan sebagai anti oksidan. Anti oksidan dapat menangkal oksidan, berkontribusi mengaktifkan diferensiasi osteoblas, proses mineralisasi dan pengurangan aktifitas osteoklas. ${ }^{31}$ Bukti epidemiologis mengindikasikan adanya hubungan asupan diet antioksidan dengan kesehatan tulang. ${ }^{31} \mathrm{CA}$ juga kaya zat mineral seperti Zn, Ca, P, K, Na, Fe, Cu, 
$\mathrm{Cr}$ dan $\mathrm{Mg} .{ }^{25}$ Studi lainnya menyebutkan bahwa diet tinggi calcium memainkan peran dalam pembentukan tulang dengan merangsang proliferasi dan diferensiasi osteoblast. ${ }^{32} \mathrm{Mg}$ dapat meningkatkan proliferasi dan rediferensiasi chondrocyte dan diferensiasi osteogenik osteoblas. ${ }^{33}$ Dengan demikian CA yang mengandung bahan aktif dan nutrisi yang tinggi dapat menjadi alternatif pilihan herba yang dimanfaatkan untuk mencegah stunting.

\section{Ekspresi Tulang \\ Tulang Rawan Tulang Keras}

Kontrol
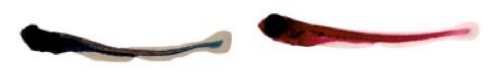

Rotenon

Rotenon+CA4
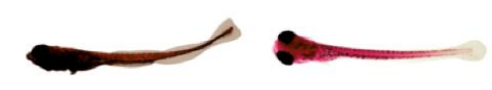

Rotenon+CA5

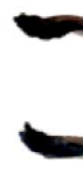

Rotenon+CA6
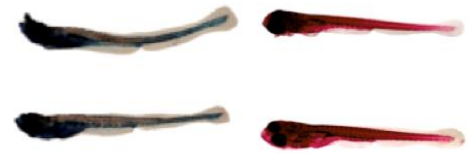

Gambar 1. Representatif whole-mount staining tulang rawan dan tulang keras larva Zebrafish usia 9 dpf

\section{Tabel 1. Efek lama pemberian ekstrak etanol Centella asiatica terhadap osifikasi tulang}

\begin{tabular}{llccc}
\hline Kelompok & $\begin{array}{c}\text { Ekspresi Tulang } \\
\text { Rawan } \\
\text { Mean } \pm \text { SD }\left(\times 10^{7}\right)\end{array}$ & $\begin{array}{c}\text { Ekspresi Tulang } \\
\text { Keras } \\
\text { Mean } \pm \text { SD }\left(\times 10^{7}\right)\end{array}$ \\
\hline Kontrol & $51,1 \pm 0,29$ & b & $3,35 \pm 0,38$ & b \\
Rotenon & $45,9 \pm 0,56$ & a & $2,80 \pm 0,53$ & a \\
Rotenon+ & $46,3 \pm 0,27$ & a & $3,17 \pm 0,28$ & ab \\
CA4 & & & & \\
Rotenon+ & $51,7 \pm 0,55$ & b & $3,43 \pm 0,50$ & b \\
CA5 & & & & \\
$\begin{array}{l}\text { Rotenon+ } \\
\text { CA5 }\end{array}$ & $50,4 \pm 0,54$ & b & $3 \pm 0,44$ & ab \\
\hline
\end{tabular}

\section{Efek Ekstrak Centella asiatica terhadap Panjang Badan}

Rerata panjang badan larva zebrafish usia 3 dpf menunjukkan tidak ada perbedaan signifikan antar kelompok $(\mathrm{p}<0,05)$ dan perbedaan panjang badan antar kelompok tidak mencapai 2 SD. Sedangkan pada $6 \mathrm{dpf}$ menunjukkan perbedaan yang signifikan antar kelompok $(p<0,05)$ seperti yang ditunjukkan pada tabel 1. Rerata panjang badan kelompok rotenon usia $6 \mathrm{dpf}<-2 \mathrm{SD}(0,17)$ dibandingkan dengan kontrol $(\mathrm{SD}=0,08)$.

\section{Tabel 1. Rerata Panjang Badan Larva Zebrafish}

\begin{tabular}{llcc}
\hline \multicolumn{1}{c}{ Kelompok } & \multicolumn{1}{c}{$3 \mathrm{dpf}$} & \multicolumn{1}{c}{$6 \mathrm{dpf}$} & $9 \mathrm{dpf}$ \\
\hline Kontrol & $3,4 \pm 0,08$ & $3,76 \pm 0,07^{\mathrm{b}}$ & $3,79 \pm 0,08^{\mathrm{b}}$ \\
Rotenon & $3,36 \pm 0,08$ & $3,59 \pm 0,09^{\mathrm{a}}$ & $3,64 \pm 0,07^{\mathrm{a}}$ \\
Rotenon+CA4 & $3,4 \pm 0,06$ & $3,73 \pm 0,06^{\mathrm{b}}$ & $3,77 \pm 0,09^{\mathrm{b}}$ \\
Rotenon+CA5 & $3,39 \pm 0,07$ & $3,76 \pm 0,07^{\mathrm{b}}$ & $3,79 \pm 0,06^{\mathrm{b}}$ \\
Rotenon+CA6 & $3,39 \pm 0,06$ & $3,74 \pm 0,08^{\mathrm{b}}$ & $3,76 \pm 0,08^{\mathrm{b}}$ \\
\hline
\end{tabular}

Paparan rotenon konsentrasi $12,5 \mathrm{ppb}$ dan CA $5 \mu \mathrm{g} / \mathrm{ml}$. CA4 paparan CA selama 4 hari, CA 5 selama 5 hari dan CA6 selama 6 hari. Notasi yang berbeda $\left({ }^{\mathrm{a}}\right.$ dan $\left.{ }^{\mathrm{b}}\right)$ menunjukkan adanya perbedaan yang signifikan antar kelompok $(\alpha=0,05)$.

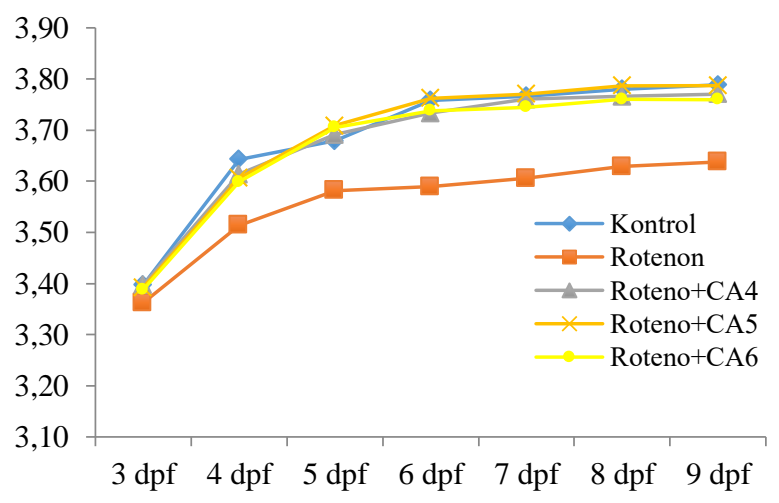

\section{Gambar 1. Grafik pertumbuhan panjang tubuh larva zebrafish}

Kriteria stunting pada anak dapat di tentukan apa bila z-score <-2 SD pada kelompok umur dan jenis kelamin yang sama. Standar antropometri anak di Indonesia didasarkan pada indeks panjang badan menurut umur. ${ }^{34}$ Pada penelitian ini analogi usia zebrafish mengacu pada penelitian Soribes, (2013) dimana $3 \mathrm{dpf}$ pada zebrafish setara dengan bayi baru lahir, 6 dpf setara dengan usia 2 tahun dan 9 dpf zebrafish setara dengan usia 8 tahun pada manusia. ${ }^{35}$ Berdasarkan hal tersebut maka kelompok rotenon memenuhi kriteria stunting. 
Rotenone memiliki berat molekul kurang 394.43 g/Mol sehingga dapat dengan mudah menembus chorion dan menimbulkan efek bagi embrio. ${ }^{36,37}$ Rotenone bersifat toksik bagi embrio dengan mekanisme kerja mengganggu transportasi elektron mitokondria yang menghambat pemanfaatan oksigen dalam tubuh pada akhirnya menyebabkan kematian sel, ${ }^{38}$ mempengaruhi perkembangan embrio dan penundaan umum yang ditandai dengan kurangnya datasemen ekor selain pembentukan somit tertunda. ${ }^{39}$

Hasil penelitian ini menunjukkan bahwa lamanya pemberian ekstrak CA sejak masa pra hatching (embrio) sampai dengan post hatching yang identik dengan post natal secara signifikan meningkatkan panjang badan di semua kelompok perlakuan $(\mathrm{p}<0,05)$. Kelompok P2 (paparan CA sampai hari ke 5) menunjukkan panjang tubuh paling optimal dibandingkan dengan P1 (paparan CA sampai hari ke 4) dan P3 (paparan CA sampai hari ke 6) yang dapat dilihat pada tabel 1 dan gambar 1 . Pemberian ekstrak CA dapat meningkatkan pertumbuhan panjang badan larva sebesar $99.6 \%$ yang di ukur pada usia 9 dpf.

Sejalan dengan hasil penelitian sebelumnya yang melaporkan bahwa pemberian ekstrak CA konsentrasi $5 \mu \mathrm{g} / \mathrm{mL}$ pada masa prehatching (3 dpf) mampu mengkoreksi panjang badan larva zebrafish model stunting yang diinduksi rotenon sebesar $97,1 \%$ melalui peningkatan IGF-1 dan peningkatan IRS, ${ }^{17}$ peningkatan ekspresi VEGF dan VEGFR-2. ${ }^{40}$ Dengan demikian pemberian Centella asiatica pada pre-hatching sampai dengan post-hatching pada zebrafish dapat meningkatkan koreksi panjang badan larva zebrafish lebih besar $2.5 \%$ dibanding hanya diberikan pre-hatching saja.

Centella asiatica kaya akan mikro nutrien seperti vitamin B1, B2 dan B3 dan vitamin $\mathrm{C}^{41}$ serta nutrisi makro seperti karbohidrat dan asam amino. ${ }^{14}$ Konsumsi makro dan mikro nutrient secara adekuat dapat mendukung proses pertumbuhan tubuh, namun jika nutrisi yang di perlukan tidak terpenuhi maka dapat menimbulkan gangguan pertumbuhan maupun gangguan metabolisme tubuh lainnya. ${ }^{42}$ Selain itu CA juga mengandung bahan aktif Asiaticoside yang dapat berperan sebagai anti oksidan sehingga mampu mentralisir efek ROS berlebih di dalam tubuh. ${ }^{43}$ Peningkatan ROS memicu terjadinya stres oksidatif dan jika berlangsung dalam jangka waktu lama dapat menyebabkan downregulation signal sehingga menurunkan respon insulin selanjutnya mengganggu proses diferensiasi, proliferasi dan jalur siklus sel. Hal ini berdampak terhadap hambatan pertumbuhan pada otot rangka dan tulang. $^{44}$

\section{KESIMPULAN}

Penelitian ini membuktikan bahwa pemberian ekstrak etanol Centella asiatica pada pre sampai dengan post hatching dapat meningkatkan osifikasi tulang sehingga dapat mencegah stunting pada zebrafish sejak pre sampai dengan post hatching.

\section{KEPUSTAKAAN}

1. de Onis M., Dewey K. G., Borghi E., Onyango A. W., Blössner M., Daelmans B. et al. The World Health Organization's Global target for reducing childhood stunting by 2015: rational and proporsed action. Maternal \&child Nutrition 2013; 9 (2): 6-26.

2. UNICEF. Tracking Progress on Child and Maternal Nutrition: A survival and development priority. UNICEF. 2009; Available from: http://www.unicef.org/publications/ index_51656.html.

3. Badan Penelitian Dan Pengembangan Kesehatan RI. 2013. Riskesdas 2013. Jakarta; 209

4. Black RE, Victora CG, Walker SP, Bhutta ZA, Christian P, de Onis M, Ezzati M, Grantham-McGregor S, Katz J, Martorell R, et al. Maternal and child underutrition and overweight in low-income and middleincome countries. Lancet. 2013; 382:42751.

5. Berkman DS, Lescano AG, Gilman RH, Lopez SL, Black MM. Effects of stunting, diarrhoeal disease, and parasitic infection during infancy on cog- nition in late childhood: a follow-up study. Lancet. 
2002;359(9306):564-71.

6. Victora CG., Adair L, Fall C, Hallal PC, Martorell R, et al. Maternal and child undernutrition: consequences for adult health and human capital. Lancet. 2008; 371:340-357.

7. MCA Indonesia. 2013. Stunting dan Masa Depan Indonesia. pp.2-5

8. Bourke CD, Berkley JA \& Prendergast AJ. Immune Dysfunction as a Cause and Consequence of Malnutrition. Trends in Immunology, 2016; 37(6), 386-398.

9. Tsang KY, Chan D and Cheah KSE. Fate of grouth plate hypertrophic chondrocytes: Death or lineage extension? Develop Growth Differ. 2015; 57(2): 179-192.

10. Helmi, Z. Buku Ajar Gangguan Muskuloskeletal. Anatomi dan Fisiologi Tulang. Cetakan kedua. Jakarta.: Salemba Medika; 2013.

11. Primihastuti D, Ali MM \& Kalsum U. Pengaruh Ekstrak Etanol Pegagan (Centella asiatica) Terhadap Ossifikasi Tulang dan Osteoklastogenesis pada Model Stunting Larva Zebrafish Model Stunting. Tidak diterbitkan. Universitas Brawijaya. Malang. 2017.

12. Wauquier, F., Leotoing, L., Coxam, V., Guicheux, J., Wittrant, T. 2009. Oxidative stress in bone remodelling and disease. Trends Mol Med. 15(1):468-77 .

13. Shen CL, Cao JJ, Dagda RY, Tenner T E.Jr, Chyu MC, \& Yeh JK. Supplementation with green tea polyphenols improves bone microstructure and quality in aged, orchidectomized rats. Calcified Tissue International. 2011; 88(6), 455-463.

14. Joshi K \& Chaturvedi P. Green Leafy Vegetable: An Overview, 2013; 4 (1), 135149.

15. Hashim P. Cetella asiatica in food and beverage application and its potential antioxidant and neuroprotective effect. International Food Research Journal. 2011; 18(4):pp. 1215-1222.

16. Randriamampionona D, Diallo B, Rakotoniriana F, Rabemanantsoa C, Cheuk $\mathrm{K}$, Corbisier AM, et al. Comparative analysis of active constituents in Centella asiatica samples from Madagascar:
Application for ex situ conservation and clonal propagation. Fitoterapia. 2007.78(7): 482-489.

17. Cory'ah, F.A., Khotimah, H., Nurdiana. 2017. Pengaruh Ekstrak Etanol Pegagan (Centella Asiatica) terhadap Panjang Badan Ekspresi Insulin Like Growth Faktor 1 (IGF-1) dan Insulin Reseptor Substrat (IRS) pada Larva Zebrafish (Danio Rario) Model Sunting Dengan Indksi Rotenon. Tidak diterbitkan, Universitas Brawijaya. Malang. 2017.

18. Khotimah H, Sumitro SB, \& Widodo MA. Zebrafish Parkinson's Model: Rotenone decrease motility, Apoptosis of Zebrafish Brain. International Journal of PharmTech Research. 2015b; 8(4), 614-621.

19. Avdesh A, Chen M, Marin-lverson MT, Mondal A, Ong D, Rainey-Smith S, Martins RN. Regular care and maintenance of zebrafish (Danio rerio) laboratory: an introduction. Jornal of Visualized Experiments. 2012; 18(69):e4196.

20. Spence R, Gerlach G, Lawrence C \& Smith C. The Behaviour and Ecology of The Zebrafish Danio Rerio. Biological Reviews. 2008; 13-34.

21. Shi-ying L, Jing-Feng C, Zhi-guo Z, Xiohua LV, Ya-jun Y, Jing-jing Z. Salvianolic acid B stimulates osteogenesis in dexamethasone-treated zebrafish larvae. Acta Pharmacological Sinica. 2016; 37: 1370-1380

22. Saravanan KS, Sindhu KM, Senthikumar KS, Mohanakumar KP. L-De-phenyl protects against rotenone-induced, oxidative stress-mediated dopaminergic neurodegeneration in rats. Neurochem Int. 2006; 49: 28-40.

23. Martin JA, Martin A, Molinari A, Morgan W, Ramalingam W, Buckwalter JA and McKinley TO. Mitochondria electron transport and couplet in articular cartilage. Osteoartritis and cartilage / OARS, Osteoarthritis Research Society. 2013; 20(4): 323-329.

24. Hock JM, Krishnan V, Onyia JE, Bidwell JP, Milas J, Stanislaus D. Osteoblast apoptosis and bone turnover. J Bone Miner Res. 2001; 16:975-984. 
25. Alikhani Z, Alikhani M, Boyd CM, Nagao K, Trackman PC, Graves DT. Advanced glycation end products enhance expression of pro-apoptotic genes and stimulate fibroblast apoptosis through cytoplasmic and mitochondrial pathways. $J$ Biol Chem. 2005; 280:12087-12095.

26. Juranek I and Bezek S. Controversy of free radical hypothesis: Reactive oxygen species-cause or consequence of tissue injury? General Physiology and Biophysics. (2005; 24(3): 263-278.

27. Lean JM, Davies JT, Fuller K, Jagger CJ, Kirstein B, Partington GA et al. A crucial role for thiol antioxidants in estrogendeficiency bone loss. J Clin Invest. 2003; 112(6), 915-923.

28. Baek KH, Oh KW, Lee WY, Lee SS, Kim, MK, KwonHS et al. Association of oxidative stress with postmenopausal osteoporosis and the effects of hydrogen peroxide on osteoclast formation in human bone marrow cell cultures. Calcified Tissue International. 2010; 87(3), 226-235.

29. Fontani F, Marcucci G, Iantomasi T, Brandi ML, Vincenzini MT. Glutathione, Nacetylcysteine and lipoic acid down-regulate starvation-induced apoptosis, RANKL/OPG ratio and sclerostin in osteocytes: involvement of JNK and ERK1/2 signalling. Calcif Tissue Int. 2015; 96:335346

30. Bellido T. Osteocyte-driven bone remodeling. Calcif Tissue Int. 2014;94:2534.

31. Domazetovic V, Marcucci G, Lantomasi T, Brandi ML and Vincenzini MT. Oxidative stress in bone remodeling: role of antioxidants. Clinica Case In Mineral Bone Metabolism. 2017; 14(2):209-216.

32. Winarto, W.R. dan M. Surbakti. Khasiat dan Manfaat Pegagan. Agromedia Pustaka, Jakarta. 2003.

33. Dou Y, Mujeeb A, Zheng Y, Ge Z. Optimalization of dual effects of $\mathrm{Mg}-1 \mathrm{Ca}$ alloys on the of chondrocytes and osteoblasts in vitro. Progres in Natural Science Material International. 24: 433440.

34. Kementrian Kesehatan RI. 2016. Info.
Situasi Balita Pendek. 2442-7659.

35. Sorribes A. The Otogeny of sleep-wake cycles in zebrafish: a comparison to humans. Frontiers in neural Circuits. 2013. 178

36. Crofton KM. Thyroid Disrupting Chemicals: Mechanisms and Mixtures. International Journal of Andrology. 2008; 31(2): 209-223.

37. Zubairi SI, Sarmidi MR, Aziz RA. A Study of Rotenone from Derris Roots of Varies Location, Plant Parts and Types of Solvent Used. Advances in Environmental Biology. 2014; 8(2): 445-449

38. Ott KC. Rotenone. A brief breif riview of its chemistry, environmental fate and the toxicity of rotenone formulation. 2006.

39. Melo KM, Oliveira R, Grisolia CK, Domingues I, Pieczarka JC, Filho JdS, Nagamachi CY. Short-term exposure to low dose of rotenone induces developmental, biochemical, behavioral, and histological change in fish. Environmental Science and Pollution Research. 2015; 22(18): pp 13926-13938.

40. Wardani, DW. Pengaruh Ekstrak Etanol Pegagan (Centella asiatica) Terhadap Ekspresi Vascular Endothelial Growth Factor Receptor-2 pada Model Stunting Larva Zebrafish Model Stunting. [Tesis]. Universitas Brawijaya. Malang. 2017.

41. Sutardi, S. Kandungan Bahan Aktif Tanaman Pegagan dan Khasiatnya untuk Meningkatkan Sistem Imun Tubuh. Jurnal Penelitian Dan Pengembangan Pertanian. 2017; 35(3), 121.

42. Prentice A, Schoenmakers I, Laskey MA, de Bone S, Ginty F \& Goldberg GR. Symposium on 'Nutrition and health inchildren and adolencents' session 1: Nutrition in growth and development nutrition and bond growth development. Proceedings of the Nutrition Society. 2006; 64(4): pp. 340-360

Bender DA. Free Radicals an Antioxidant Nutrients. In: Murray K, Bender DA, Botham KM, et al. Eds. Harper's Illustrated Biochemistry, Ed $28^{\text {th }}$ Mc Graw Hill Lange 2009;482-86. 